\title{
Трещиностойкость, прочность и сопротивление окислению композитов на основе молибденовой матрицы и волокон силикатов иттербия
}

\section{Fracture toughness, strength and oxidation resistance of ytterbium- silicates-based-fibres/molybdenum- matrix composites}

\section{А. А. Колчин, В. М. Прокопенко, \\ М. Ю. Никонович, С. Н. Галышев, \\ О. Ф. Шахлевич \\ Институт физики твёрдого тела РАН}

Поступила в редакцию 04.12.2020, принята к печати 15.12.2020
Andrew A. Kolchin, Vyacheslav M. Prokopenko, Maxim Yu. Nikonovich, Sergei N. Galyshev, and Olga F. Shakhlevich

Institute of Solid State Physics of Russian Academy of Sciences

\section{Абстракт}

Получено семейство композитов на основе молибденовой матрицы, армированной новыми оксидными волокнами моносиликата $\mathrm{Yb}_{2} \mathrm{SiO}_{5}$ и дисиликата иттербия $\mathrm{Yb}_{2} \mathrm{Si}_{2} \mathrm{O}_{7}$. Изучены их микроструктура, прочность, трещиностойкость и сопротивление окислению. Величина трещиностойкости композитов достаточно высокая: средняя величина критического коэффициента интенсивности напряжений составляет около $20 \mathrm{MПа} \cdot \mathrm{M}^{1 / 2}$. Композиты с волокнами $\mathrm{Yb}_{2} \mathrm{O}_{3}-\mathrm{Yb}_{2} \mathrm{SiO}_{5}$ характеризуются высокой прочностью при комнатной и при высоких температурах, вплоть до $1400^{\circ} \mathrm{C}$. Сопротивление окислению композитов при температурах 1000 и $1100^{\circ} \mathrm{C}$ выше, чем у молибдена.

\section{Abstract}

A family of molybdenum matrix composites reinforced with new oxide fibres based on ytterbium monosilicate $\mathrm{Yb}_{2} \mathrm{SiO}_{5}$ and disilicate $\mathrm{Yb}_{\text {- }}$ ${ }_{2} \mathrm{Si}_{2} \mathrm{O}_{7}$ is obtained and their microstructure, strength, fracture toughness and oxidation resistance are studied. Fracture toughness of the composites is sufficiently high; the average value of critical stress intensity factor is about $20 \mathrm{MPa} \cdot \mathrm{m}^{1 / 2}$. The composites with $\mathrm{Yb}_{2} \mathrm{O}_{3}-\mathrm{Yb}_{2} \mathrm{SiO}_{5}$ reinforcing fibres are characterized by the highest values of strength at room and high temperatures, up to $1400^{\circ} \mathrm{C}$. Oxidation resistance of the composites at temperatures of 1000 and $1100^{\circ} \mathrm{C}$ is much higher than that of molybdenum.

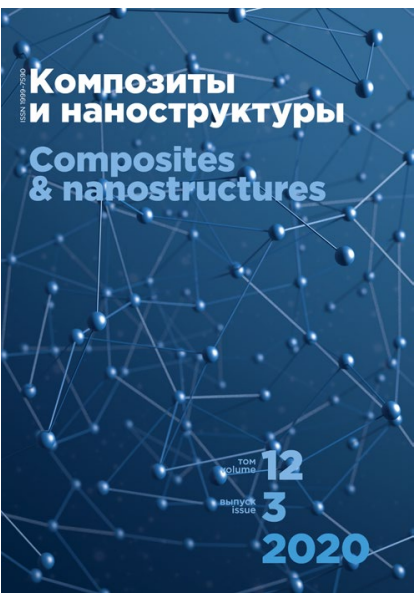

